\title{
ITALY AND AFRICA: COLONIAL AMBITIONS IN THE FIRST WORLD WAR
}

\author{
By Robert L. Hess
}

IN accordance with the secret Treaty of London of 26 April I9I 5, Italy entered the First World War in exchange for certain promises made to her by Great Britain and France. The treaty provided for concessions to Italy in Europe, the Mediterranean, Asia Minor, and Africa, but the concessions to which Great Britain and France agreed were not regarded by the Italians as the limit of their demands.

By Article 13 of the Treaty of London, Italy would receive extensions of her territory in Libya, Eritrea, and Somaliland if England and France should enlarge their colonial empires by absorption of the German colonies. All this is well known and has been covered adequately by Toscano and others. $^{1}$ It is not generally known, however, that the Italian Colonial Ministry formulated a much more extensive official post-war programme, which went far beyond the claims found in the London Pact and is particularly impressive in the scope of its colonial ambitions in Africa. Beer considered such Italian plans to be unofficial, drummed up by nationalists like the journalist Piazza and members of the Italian Colonial Institute. ${ }^{2}$ The irresponsible way in which these writers advanced their unofficial programmes has led more than one scholar to discount their value as an indication of official policy. Yet it must be recognized that these unofficial programmes were but an echo of the extensive maximum and minimum programmes proposed by the Colonial Ministry to the Italian government. Behind a veil of secrecy, hundreds of letters and telegrams from 1913 to I919 document a resurgence of Italian colonial ambitions in Africa. These documents, which are to be found in the archives of the former Colonial Ministry, were printed in a four-volume secret edition of fifty copies, intended for circulation only within the governmental ministries. ${ }^{3}$ The story told by these documents sheds new light on the role that Italy hoped to play in Africa and offers a fascinating case-study of the highly imaginative scope of the ambitions of one European imperialist Power. Perhaps too these documents mark a closing chapter, or an epilogue, to the history of the partition of Africa among the European Powers.

To the best of this writer's knowledge, only three other authors have

1 The best account is probably M. Toscano, Il Patto di Londra (Bologna, 1934).

${ }^{2}$ G. L. Beer, African Questions at the Peace Conference (New York, 1923), pp. 391-2.

- Ministero delle Colonie, Direzione Generale degli Affari Politici e dei Servizi relativi alle Truppe coloniali, Affrica Italiana: Programma massimo e Programma minimo di Sistemazione dei Possedimenti italiani nell' Affrica orientale e settentrionale, Rome, Tipografia del Senato di Giovanni Bardi, 1917-20, four volumes. Confidential Series Number 9. Secret edition of fifty copies. Hereafter referred to as $A . I$. 
made use of these sources. The first to throw light on the existence of the documents was Mario Toscano, who in 1937 accurately described the contents of the war-time colonial programme. ${ }^{4}$ Toscano's work, however, was purely descriptive and placed the Italian programme in an outdated context: justification of Fascist action as the only means to achieve any colonial goals. Given the circumstances of 1937 , it is understandable that Toscano did not analyse the programme in depth in terms of its implications. ${ }^{5}$ It is less certain why Toscano failed to mention the ultra-secret nature of the programme and the fact that these documents were published in a limited secret edition. Another writer of the Fascist period, Francesco Salata, also described the colonial programme, but he too failed to mention its confidential nature. ${ }^{6}$ Although a chapter of his book is devoted to the programme, Salata does not attempt to analyse the documents. To his credit, he admits that the sole purpose of his writing was to inform the public of the basis of current Italian claims in Africa. Most recently, G. A. Costanzo has published a study of Italian policy in East Africa based almost wholly on these documents. ${ }^{7}$ Yet this author cannot agree with Costanzo's contention that the basis of Italian policy in East Africa was the assumption that Ethiopia would maintain its integrity and independence. Moreover, the documents used by Costanzo cover only part of the larger Italian policy for the whole African continent, a study of which is certainly worth while.

Renewed Italian interest in Africa was first evident in several talks of a general nature held in Rome in 1913 and 1914 by British Ambassador Sir James Rennell Rodd and Giacomo Agnesa, Director-General of Political Affairs in the Ministry of Colonies. After the death of Menelik II in I9I3 and the accession to the throne of the controversial Lijj Iasu, the political situation in Ethiopia was especially fluid. In August 1913 the Italian Colonial Minister, Pietro Bertolino, proposed that Italy determine more precisely her interests in East Africa, within the limits of Article 4 of the I 906 Tripartite Agreement by which England, France, and Italy recognized cach other's special interests in Ethiopia. ${ }^{8}$ Later that year the Agnesa-Rodd talks left the Italian with the impression that the British Ambassador was

4 M. Toscano, 'Il Problema coloniale italiano alla Conferenza della Pace' in Rivista di Studi Politici Internazionali, iv ( 1937$), 263-97$.

${ }^{3}$ Toscano seldom interprets. At the conclusion of his essay, however, he wrote, 'The definitive settlement of our colonies in East Africa . . . had to be realized in a totalitarian way.' (P. 295.)

' F. Salata, Il Nodo di Gibuti (Milan, 1939). The text of the war-time colonial programme as formulated by the Colonial Ministry is given verbatim (pp. 264-76).

' G. A. Costanzo, La Politica italiana per l'Africa orientale (Rome, 1957).

${ }^{8}$ The full text of the Agreement appears in Sir E. Hertslet, The Map of Africa by Treaty (London, 1909), 3rd ed., 11, 440-4. By the terms of Article 4, France was concerned with the Djibouti-Addis Ababa railway; England wished to be certain of the status of the headwaters of the Nile; and Italy desired a vague 'territorial union' by means of an undefined corridor connecting Eritrea and Somalia somewhere west of Addis Ababa. A.I., I, 86-7, confidential memorandum from Agnesa to the Minister of Colonies and the Under-Secretary of State for Colonies, Rome, 15 August 1913. 
sympathetic to the Italian cause and that Italy might secure new arrangements to end her dissatisfaction with the vague clauses of the 1906 Treaty: 'there may be new grounds for agreement'. ${ }^{9}$ For the time being, however, the British were content only to listen to the Italian's case. The British thereby avoided immediate action, while Italy was ready to support English claims in Ethiopia in everything but territorial acquisitions. ${ }^{10}$

Out of these exploratory talks the Italian programme developed. The Colonial Ministry went on to formulate a plan of attack to achieve the possession of Kismayu, 'a question of vital importance for southern Italian Somaliland'.11 'The Colonial Ministry proposed that the British cede to Italy a triangle of land at Kismayu, including the right bank of the River Juba; the Italians would then grant to the English the same concessionary installations and rights of transit that Italians had enjoyed at Kismayu since I $89 \mathrm{r}^{12}$ In effect, they wished to reverse the landlord-tenant relationship they had with the British at the mouth of the Juba. Should the British yield, the Italians hoped to attract to Kismayu the entire trade of the Juba valley and, eventually, the commerce of southern Ethiopia. Here again the obscure served as a prologue to the formulation of larger goals.

Although negotiations for the cession of the Kismayu triangle failed to materialize, Italian colonial aspirations received a fresh impetus from the outbreak of war. Anticipating the intervention of Italy in the war, Ferdinando Martini, Minister of Colonies in 1914, sought to define Italian interests so that 'in case of our intervention, the Powers on whose behalf we intervene, if victorious, can make special concessions to Italy in a general settlement in Africa' ${ }^{13}$ In a series of eight sweeping memoranda, the Ministry proposed the cession of French Somaliland to Italy, as well as control of the almost completed railway to Addis Ababa; the cession of Kismayu; the recognition of British rights in the Lake Tana area in exchange for a corridor between Eritrea and Somaliland; an Anglo-Italian agreement on Arabia; the cession of Kassala in the Sudan to Italy; a modification of the Cyrenaican-Egyptian border; an Anglo-Italian accord concerning the future of the Portuguese colonies; and the 'protection' of Italian rights and interests in Ethiopia. But all this was of little avail. The Italians were soon thwarted in their attempt to spell out their colonial

- Archivio del ex-Ministero dell'Africa italiana, pos. 171/3, f. 22, confidential minutes of a colloquium between Agnesa and Rennell Rodd, Rome, 20 December 1913. Rennell Rodd makes no mention of these talks in his memoirs. Hereafter the Archives will be referred to as A.M.A.I.

${ }^{10}$ A.M.A.I., pos. $171 / 3$, f. 22, confidential minutes of a colloquium between Agnesa and Rennell Rodd, Rome, 2o July 1914.

${ }^{11}$ A.M.A.I., pos. $171 / 3$, f. 22, memorandum on Kismayu dated ' 1914 ', p. 15.

12 Ibid., p. 192. In the twenty-one years of Italian administration in Somalia, little had been done to improve the territory's port facilities; large European ships had to load and unload offshore and have their cargoes ferried across the reef to the beach at Mogadishu or Brava. Kismayu, unlike Mogadishu or Brava, had a natural sheltered bay, where investments in harbour construction would have more value than elsewhere.

1s A.I., 1, 1-2, draft of a letter from the Director-General of Political Affairs to the Minister of Colonies, November 1914. 
demands more precisely in the London Treaty, although they did fully expect that their Allies would fulfil the vague conditions of Article 13. Nothing further came of the Colonial Ministry's proposals until after Italy declared war on Germany on 28 August 1916.

Early in October 1916 the Colonial Minister, Gaspare Colosimo, approached the Foreign Ministry with 'the necessity to propose a programme for the settlement of our colonial interests in Africa, in anticipation of a discussion of the conditions of peace'. ${ }^{14}$ Spurred on by his conversation with the Foreign Minister and eager to enlarge Italy's colonial possessions, Colosimo drew up a comprehensive programme based, in part, on the memoranda of his predecessors. By ${ }_{5} 5$ November Colosimo had completed his manuscript and presented the Foreign Ministry with a programme classified 'secret'. ${ }^{15}$ Rarely has any colonial ministry drafted such ambitious colonial projects for a nation whose claim to 'compensation' was so tenuous.

Colosimo envisaged the colonial question as part of a general peace settlement by which a new balance of power in Africa would be established. To strengthen his argument, he presented a threefold rationale for the enlargement of Italy's African Empire. Firstly, because of 'unfortunate events of the past', Italy had everything to gain territorially. Secondly, although the Italians had made no direct contribution to the war effort in Africa, nevertheless they had made an indirect contribution to the Allied cause in Africa by bottling up the Austrian Navy in the Adriatic. Thirdly, the German territories occupied by the French and British could serve as pawns for compensation in the settlement of more important European or Asian questions. Africa, then, was to serve the same function in a peace settlement as it had in the Zanzibar-Heligoland arrangement of 1890 or in the series of ententes preceding the war.

Actually, the Minister of Colonies drew up two plans of action. Both the maximum and the minimum programmes, in turn, were divided into a part dealing with East Africa and another with North Africa. The maximum programme for East Africa called for the renunciation of British and French interests in Ethiopia and the 're-establishment ... of that which should have been under our exclusive influence if sad events, human errors, and, let us even say, ill-will on the part of our present allies had not caused the collapse of twenty-five years of Italian diplomatic and colonial activity'.16 To undo the harm done in the existing arrangements in East Africa the programme called for the revision of the 1906 Tripartite Agreement and a return to the Anglo-Italian Protocols of 1891 and 1894 which placed Ethiopia in an exclusively Italian sphere of influence; at one stroke Italy hoped to turn back the clock to pre-Adowa times.

14 A.I., I1-I, 209-10, letter no. 9683 from Minister of Colonies Colosimo to Foreign Minister Sonnino formulating maximum and minimum colonial programmes (secret), Rome, 15 November 1916.

15 Ibid.

${ }^{16}$ A.I., II-I, 212 , memorandum on East Africa appended to letter no. 9683 . 
Specifically, the programme demanded of England cession of the Somaliland Protectorate, Kismayu and all of Jubaland, and Kassala and the Sudanese Province of Taka; guarantee of Italy's interest in Arabia; and the preservation of the status quo in the Red Sea. In the event of a change in the status quo, Italy would occupy the Farasan Islands off the coast of Arabia opposite Massawa. In return for these concessions, Italy would negotiate a new and secret accord with England to guarantee the headwaters of the Nile, trading rights, and certain pasturing and watering rights for British-protected tribesmen, and to purchase certain governmental properties in Somaliland, Jubaland, and Taka. A flat statement was made that Italy owed nothing to Great Britain for these concessions. From the French, whom the Italians intended to exclude from Ethiopia, the programme demanded the cession of French Somaliland and the nearly completed Djibouti-Addis Ababa railway. In exchange for these concessions, the Italian government would assume all debts and responsibilities of the French government vis-à-vis the Ethiopian government and the railway company; vague mention was made of a French naval station in the Red Sea, but the African coast was definitely excluded from consideration. ${ }^{17}$

Furthermore, in North Africa the Italians had ambitions to obtain the hinterland of Libya, which Colosimo defined as an area of 2,525,000 square kilometres with a population of more than 2,000,000. Colosimo claimed that the Franco-British Convention of 1898 and declaration of 1899 which divided the so-called Libyan hinterland 'behind Italy's back' was an act of villainy that could be undone only by securing to Italy the important caravan routes from Ghadames to Ghat and Tummo, and by 'returning' to Tripolitania the northern part of the Chad basin, including Kanem and Wadai, as well as all the important oases in the Sahara between Tripolitania and the Nigerian hinterland. In addition, the programme called for a rectification of the Cyrenaican-Egyptian border to include Jarabub in Italian territory. 'Given that the arrangement in the Libyan hinterland was forced upon us, no compensation should be made, inasmuch as this concerns a tardy recompense for one of the greatest outrages recorded in nineteenthcentury colonial history to the injury of a third interested Power.'18

If realized, this hardly modest programme would have given the Italians control over the Red Sea through bases in Eritrea and in either Arabia or the Farasan Islands; the Libyan colony would have extended across the Sahara to Lake Chad; and the majority of Somalis in French Somaliland, British Somaliland, and the Trans-Juba area (then part of Kenya) would have been placed under the Italian flag. A free hand in Ethiopia, if we are to judge by both earlier and later events, might also have had serious implications for the political independence of that Empire. It is interesting

"A.I., 11-1, 21 3-16, memorandum entitled 'Maximum Program: East Africa' appended to letter no. 9683 .

${ }^{18}$ A.I., II-I, 218 , memorandum entitled 'Maximum Program: North Africa' appended to letter no. 9683 . 


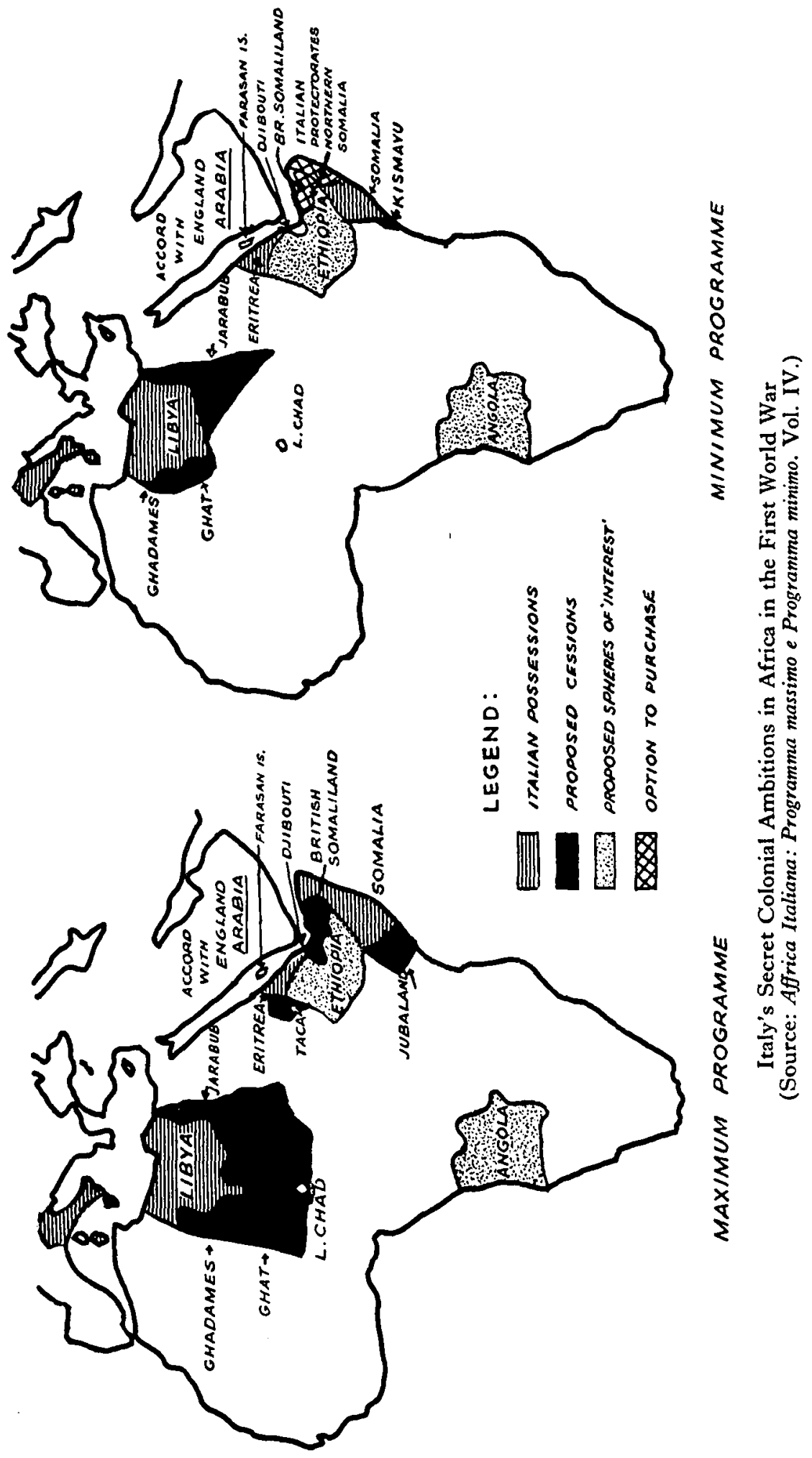


to note also that the tone and manner of the maximum programme is one which assumes beyond doubt the right of Italy to make such demands. No consideration was given to the possibility that carving a huge block of Italian territory out of the Central Sudan might be counter to the east-west ambitions of the French in the Sudan. It was taken for granted, perhaps mistakenly, that Italy was one of the great European Powers in Africa.

The minimum programme was barely distinguishable from the maximum programme for colonial expansion in Africa. Here too Italy sought a new balance of power in Africa in consequence of the occupation of the German colonies by the forces of France and England and in compensation for her war effort. The goals of the East African phase of the programmes, maximum and minimum, were identical: 'In order to obtain the full worth of Eritrea and Somalia, which by themselves amount to very little, Italy must have a free hand in Ethiopia, exactly what she was aiming for when she occupied Massawa and when she first acted in the Indian Ocean.'19 Here then is a clear refutation of the contention that Italy intended to let Ethiopia maintain its integrity and independence.

As minimum compensation for Italy's contribution to the war effort, the Colonial Ministry demanded the abrogation of the Tripartite Agreement of 1906 and a return to the Protocols of 1891 and 1894 ; French disinterest in Ethiopia and the cession of French Somaliland and the railway to Addis Ababa; new secret accords with England to determine the future of an Fthiopia in which England's special interests would be recognized; a guarantee of Italy's interests in Arabia and her right to occupy the Farasan Islands.

Thus far the minimum programme repeated many of the demands of the maximum programme. The differences indeed were minor: instead of cession of British Somaliland, the Colonial Ministry proposed an Italian option to purchase that territory in the event that the British should withdraw completely, in return for which Italy would give the British a similar option to purchase northern Italian Somaliland, which was a burdensome protectorate for the Rome government; rather than all Jubaland, Italy would be satisfied with the Kismayu triangle; and no mention was made of Kassala-Taka. In North Africa the programme did become more of a minimum one, for the Italian claims were modified to include only possession of the Ghadames-Ghat caravan route and the Oasis of Jarabub, and the establishment of consular and commercial agencies in French Saharan Africa. Evidently the extensive hinterland of Libya and one of the greatest colonial outrages of the nineteenth century could both be overlooked if necessary; it is difficult to avoid the conclusion that East Africa, in particular Ethiopia, was the main goal of the Colosimo programmes.

Three days after Colosimo completed the colonial programme it was in

19 A.I., II-I, 209-10, letter no. 96$\rangle_{3}$. Here I would disagree with Costanzo, who claims that Italy had ever been aiming at full jalnrizzazione of her Eritrean and Somali colonies. A.M.A.I. documents indicate that the Italian goal had been Ethiopia, and that Eritrea and Somalia were regarded only as mean:s to that end. 
the hands of the Foreign Minister, Sonnino. Much depended on the course of the war, and Sonnino could do little but file away Colosimo's programme until the time should come to use it. For Colosimo, however, the programme became almost an idée fixe; much of his time as Colonial Minister seems to have been spent in refining the programme. Early in January 1917 , revealing a streak of inflexibility in his nature, Colosimo attempted to preserve the structure of each plan as a unity in itself : 'It must be presumed necessary', he wrote, 'to have in reserve other requests which are not part of the maximum or of the minimum programme, but which can serve as a ground for understanding in order not to diminish too much the former and to reinforce the latter programme.' 20 Returning to the Martini proposals of 1914, Colosimo concentrated on the possibility of using the future of the Portuguese colonies as a bargaining point. Aware of the financial difficulties of the Portuguese government and the precedent of an AngloGerman agreement on those colonies, Colosimo debated whether or not he should draft another maximum programme relative to all Portuguesc colonies in Africa and a minimum programme relating only to Angola, where Italian capitalists apparently were willing to invest money that they would not invest in the Italian colonies. Employing a familiar technique, Colosimo proposed a bilateral Anglo-Italian agreement on the Portuguese colonies, with the possibility of outright purchase of southern Angola or the creation of spheres of influence. And, once again, the Colonial Minister consciously sought to exclude France from a large area of Africa.

Foreign Minister Sonnino's response to the maximum-minimum programme and the Angola corollary was far from encouraging. There was, first of all, a delay of more than six weeks before Colosimo received word of Sonnino's reaction to the plan. When word finally came, the Foreign Minister, who was more interested in furthering Italian interests in Asia Minor, refused to take a definite stand on the matter. ${ }^{21}$ Both African programmes, he claimed, depended on the uncertain outcome and development of 'international events', and hence the Foreign Ministry would not examine the maximum programme, which would be difficult to realize even under the most favourable circumstances. ${ }^{22}$ Sonnino preferred to work within the framework of the 1906 Agreement; the British desire to secure Lake Tana and the headwaters of the Blue Nile could be supported by Italy in return for the cession of Kismayu and British pressure on France to yield Djibouti and the railway; England might even grant France a naval station on the Arabian coast of the Red Sea. Thus part of the minimum programme might be capable of fulfilment, but only as part of a future general peace settlement, 'not before, and not after-with the danger otherwise of making a completely useless sacrifice'. ${ }^{23}$

${ }^{20}$ A.I., II-1, 657-62, letter no. 80 from the Minister of Colonies to the Foreign Minister (secret), Rome, 4 January 1917.

21 Toscano, 'Il Problema coloniale italiano alla Conferenza della Pace', pp. 272-3.

32 A.I., II-I, 665-7, letter no 5 from the Foreign Minister to the Minister of Colonies (confidential), Rome, 7 February 1917.

23 Ibid. 
Annoyed by Sonnino's stand, Colosimo took issue with his whole approach to the colonial question. British occupation of Lake Tana was to be considered only as an extrema ratio, to be avoided at all costs, for it would be 'a thorn planted in the side of Ethiopia by the Power controlling the Sudan and British East Africa, with the consequent inevitable absorption by the English of the best part of Ethiopia'. Such an arrangement could lead only to future Anglo-Italian wrangling over Ethiopia; the basic problem of interpreting Article 4 of the 1906 Agreement would not be resolved. Rather sanguinely, Colosimo proposed that the best way to come to an agreement with England and France would be to

draw a line that includes Ethiopia and the English and French colonies of the eastern horn of Africa in an exclusively Italian sphere, finding compensations for France and England in Africa (the German colonies) and in Asia (Turkey). With that as a maximum criterion, it will be easy to come to an understanding along these broad lines. ${ }^{24}$

Of course, what Colosimo was proposing was not the means to an end, but the end itself: realization of the maximum programme.

There the matter was tabled for nearly a year while Italy fought the exhausting battle of the Isonzo and the disastrous Caporetto campaign, in which she lost more than 300,000 men as prisoners to the Central Powers. Late in October 1917, as a result of the military defeat, a new Cabinet was formed, headed by Orlando, a close personal friend of Colosimo. Now the Colonial Minister's voice could be heard in powerful circles, and until the Peace Conference the Prime Minister paid careful attention to Colosimo's words.

Colosimo was particularly concerned about the publication by Pravda of the full text of the secret Treaty of London in November 1917, Lloyd George's support of the principle of national self-determination, and Wilson's Fourteen Point message of January 1918. All this was ominous, for a basic assumption underlying the Italian post-war colonial programme was that Britain and France would take the German colonies and thus be compelled to give Italy compensation. ${ }^{25}$ Urgently he wrote to the Foreign Minister that in no way at all must the Pandora's box of self-determination be opened at the Peace Conference. Italy had to prepare herself to combat this pernicious idea. ${ }^{26}$ Colosimo almost hoped that England would annex the German colonies and so be forced to give compensation to Italy. But whether the colonies were annexed or even restored to Germany, the Colonial Minister persisted in his belief that Italy's allies must recognize her claims in Africa as a 'political necessity' and consider the settlement of

24 A.I., II-1, 669-75, letter no. 1127 from the Minister of Colonies to the Foreign Minister (secret), Rome, 24 February 1917.

${ }^{2 s}$ A.I., 11-2, 87-8, letter no. 1546 from the Minister of Colonies to the Foregin Minister (secret), Rome, io March igi 8 .

${ }^{26}$ A.I., II-2, 64-71, letter no. 1017 from the Minister of Colonies to the Foreign Minister (confidential, urgent), Rome, I 5 February 1918. 
Italian colonial interests as a conditio sine qua non 'in order that a European peace be also an African peace'. ${ }^{27}$

Colosimo must no doubt have been heartened by dispatches from London and Paris in March 1918. Marchese Imperiali reported from the British capital that there was no real or definite unity of opinion in England on the colonial question. Britain was caught, he wrote, between the interests of her allies and strong currents of domestic democratic thought. Too many things were in a state of transition to make any definite judgments. ${ }^{28}$ From Paris Ambassador Bonin reported,

I believe that I am not in error if I report that the declarations of the American President and of the English Labour Party have given no cause for preoccupation in official circles here, where they are considered simply utopian. ... I need not add that political conditions in the French colonial empire are such that any French Government would be decisively opposed to such a principle. . . . Public opinion about colonial self-determination can be summed up in the brief reply made to me by $M$. de Margerie when I requested his judgment on the idea of Wilson and the Labourites: C'est simplement absurde. ${ }^{29}$

The Italian Ambassador's conclusion was that Italy could count on French support against any proposal for a plebiscite in the colonies.

Although the maximum and minimum colonial programmes were kept strictly secret, Italian aspirations found an echo in expansionist writers. Toscano hints that the Colonial Ministry may have deliberately leaked news of its programme to the Press. ${ }^{30}$ Certainly the works of Giuseppe Piazza lend credence to this hypothesis. ${ }^{31}$ In the same year that the maximum and minimum programmes were formulated, G. A. Rosso, a political writer, presented his thesis that Italy, for her war-time contributions, deserved an 'interest' in Libya and its hinterland, Eritrea and the Red Sea, and Somalia and Ethiopia. Rosso argued not only for compensation but also for the need to establish a new balance in Africa between England, France, and Italy. His arguments of compensation, balance of power, and the need for ports (Kismayu) reflected almost verbatim the contents of the secret documents. He too felt that France should yield Djibouti, that England should cede at least Zeila and Berbera in British Somaliland, that the Trans-Juba should go to Italy. Moreover, he presented additional territorial demands for the Near East, Anatolia, and Yemen that bear a remarkable resemblance to articles in the still secret

"A.I., 11-2, 88, letter no. 1546 .

${ }_{28}$ A.I., II-2, 94-8, report no. $1120-b i s / 363$ from the Ambassador in London to the Foreign Minister, London, 23 March 1918.

${ }^{20}$ A.I., II-2, 99-100, report no. $1190 / 371$ from the Ambassador in Paris to the Foreign Minister, Paris, 25 March 1918.

${ }^{30}$ Cf. Toscano, op. cit., p. 273.

${ }^{1}$ G. Piazza, La Nostra Pace Coloniale (Rome, 1917), based on the journalist's articles in the Rome Tribuna, the Rivista Coloniale, and the Nuova Antologia from June I9I6 to March 1917 , is a good case in point. Piazza claims to "characterize decisively and courageously the "objectives" of the war. . . Any Italian Government which does not see this ... would undo the outcome of the war.' (P. 6.) 
London Treaty and to the demands formulated in the maximum-minimum programmes. ${ }^{32}$

Franco Caroselli, in a scholarly study of German aspirations for the creation of an empire in Mittelafrika, however, was completely unaware of the aims and goals established by the Colonial Ministry. The young Caroselli did not pose the outright demands made by Rosso, but argued on a higher, if less realistic, plane. Ruling out self-determination for Africa's 'still barbarous peoples', Caroselli proposed what he considered to be the ideal solution for the colonial programme-a repartition of Africa. Caroselli categorically claimed that

the particular interests of Italy coincide with the highest idealistic aims followed by free peoples. ... If a new partition of African colonial possessions must take place, Italy will oppose in that continent, as elsewhere, [the idea that] new acquisitions serve as a pretext for the affirmation of any hegemony whatsoever. To participate in the great work of colonization, she can boast of a spotless past, inasmuch as in that task she has never forgotten the high civilizing mission that is her duty. ${ }^{33}$

Repeating an oft-quoted slogan of the Allied Powers, Caroselli claimed that Italy 'was certainly not pushed into this war by imperialist goals, but only by the task of completing her national unity. ... No longing for colonial conquest constitutes her war aims. ${ }^{34}$ Caroselli, a member of the Colonial Service, finished writing his book on 29 July 1918 ; it is difficult to believe that he was unaware of Article 13 of the Treaty of London as read to the Chamber of Deputies in Rome on 13 February $1918 .^{35}$ A more likely hypothesis is that the Ministry of Colonies, while pressing its imperialist programme, preferred to pay lip-service to idealism rather than arouse public opposition.

One consequence of this policy of secrecy was that the Italian Legation in Addis Ababa was ignorant of Rome's colonial goals. While the British Agent in Ethiopia, Wilfred Thesiger, pursued a vigorous policy, Colli, the Italian Agent, could only report back to Rome of the turbulence created in Ethiopia by the collapse of Lijj Iasu and the subsequent rise to power of the Empress Zauditu and Ras Tafari. Against this background Thesiger took the initiative and proposed to Colli that Rome and London search together for a solution to the Ethiopian problem and 'eliminate any interference and interest on the part of the Paris Government'. The English representative had reached the conclusion that the only solution was elimination of the French through transfer of the port of Djibouti to

${ }^{32}$ G. A. Rosso, I Diritti d'Italia Oltremare (Rome, I9 16), pp. 50-1, 60-1, 74-9.

3s F. S. Caroselli, L'Affrica nella Guerra e nella Pace d'Europe, I9II-I9-(Milan, 1918), pp. 393-4.

34 Ibid., p. 360 .

${ }^{35}$ Caroselli continued to rise through the ranks of the Colonial Service in the years that followed. From 1937 to 1940 he served as Governor of Somalia. After the Second World War he acted as President of the Committee for the Documentation of Italy's Work in Africa, heir to the Archives of the ex-Ministry of Colonies (A.M.A.I.). 
another Power-England. With France eliminated from the Ethiopian scene, Italy and Great Britain could then agree on a modus procedendi for a definitive settlement of their Ethiopian interests. Colli, in fact, would not have reported these aggressive British intentions if Thesiger had not claimed that the British government was considering implementing his policy, with the whole-hearted support of Sir Reginald Wingate, High Commissioner for Egypt. ${ }^{36}$

Armed with the Colli report, Colosimo put additionai pressure on the Foreign Minister to adopt an aggressive East African policy. The Minister of Colonies deeply suspected Britain's motives in Djibouti, through which port flowed a great trade in arms and munitions with Ethiopia. Once England obtained Djibouti, after compensating France with territory in West Africa, would the territory then be ceded to Italy? And yet the Ethiopian problem would remain unresolved as long as France held Djibouti. Nor was England at Djibouti an acceptable solution. Daringly, Colosimo threatened that 'if one wants the alliance between England, France, and Italy to continue after the war, and to be an alliance in Africa too, it is necessary that Djibouti become Italian and not remain a thorn in the side of Italy, a source of continual divergences and conflict'. Cession of Djibouti from France to England to Italy would be acceptable only if the minimum plan for East Africa were adopted. Continuing his syllogism, Colosimo bluntly stated that there would be no settlement at all unless 'Ethiopia were left entirely in the exclusive sphere of influence of Italy'. ${ }^{37}$

In general the outlook for Colosimo's colonial programme in June Igr 8 was not encouraging. France was operating counter to Italy in the question of arms importation into Ethiopia. England had expressed, through Thesiger, the vague possibility of annexing Djibouti to British Somaliland. And in North Africa a Turkish offensive had made threatening headway; Italy had yet to reoccupy large areas of Tripolitania. Indeed, the Sultan's son had landed in occupicd Tripolitania, and it was feared that Turkey might reopen the question of Libya at a peace conference. ${ }^{38}$ Far from being discouraged, now more than ever Colosimo felt that Sonnino must support his colonial programme. Colosimo sought to enlist the aid of Prime Minister Orlando, his personal friend, whom he familiarly addressed as 'amatissimo Presidente e carissimo amico'. Co-operation between England and France in East Africa had to be avoided at all costs. The means to prevent such an alignment was clear to Colosimo: Orlando was urged to pay attention to his 'inexorable syllogism'. ${ }^{39}$

${ }^{36}$ A.I., II-2, 135-9, report no. 28 from Colli, Italian Consul in Ethiopia, to the Foreign Minister (confidential), Addis Ababa, 5 April 1918.

${ }^{37} A . I .$, II-2, $148-54$, letter no. 3245 from the Minister of Colonies to the Foreign Minister (secret), Rome, I June 1918.

${ }^{38}$ A.I., II $-2,140-7$, letter no. 3066 from the Minister of Colonies to the Governor of Tripolitania (highly confidential), Rome, 31 May 1918.

${ }^{39}$ A.I., II-2, 164-5, letter no. 341 I from the Minister of Colonies to the Foreign Minister (confidential, personal), Rome, 3 June 1918 ; 192-8, letter from the Minister of Colonies to the Prime Minister, Rome, 7 June 1918. 
When Baron Sonnino departed for Paris for armistice negotiations early in October, Colosimo felt that the door was opened for realization of Italy's maximum programme. Colosimo himself drew up the conditions for an armistice with Turkey, and added as a second thought harsh conditions that were not to be included in the armistice signed on 2 November 1918.40 The Colonial Minister was rudely shocked when Sonnino telegraphed to Rome: 'For reasons of rapidity armistice was negotiated and concluded directly between England and Turkey on general bases fixed in an earlier conference. Neither we nor other allies were consulted on modifications later introduced.' 41 This was but the precursor of future developments.

Meanwhile Colosimo drafted a memorandum to be shown to Colonel House in a bid for American support of Italian colonial aspirations. The line of reasoning was a familiar one. Italy based her claims on pre-war rights, on rights born during the war, and on the necessary consequences of the post-war period, as interpreted by Italy. The wording was particularly clever:

If one wants a peace ... that is just, equitable, and lasting, one that corresponds to the moral goals for which President Wilson is working, it is necessary to anticipate and avoid future troubles between the Allies of today in order that they remain Allies tomorrow, reestablishing on new bases the future relations of peace and of alliance in Africa as well as in Europe, eliminating any and all reasons or occasions for discord or conflict.

The memorandum then stated the goals of the maximum programmetransfer of the French Somali coast, British Somaliland, and Jubaland to Italy, and exclusive Italian influence over Ethiopia; recognition of Italian interests in the Red Sea, and the extensive claims to the Libyan hinterland. Modestly, Colosimo's memorandum concluded, 'A solution of imperialism is not asked, but simply an equitable solution of equilibrium required by the necessities of life, of development, of lasting peace-a solution which will permit Italy to labour and to prosper without doing injury to anyone.' 42

While Italy allegedly renounced an imperialist solution, both the Foreign Ministry and the Colonial Ministry were deeply concerned about events transpiring in Ethiopia. On I I November, coincidental with the signing of the German armistice, the Ethiopian government issued two decrees outlawing all aspects of the slave trade and of commerce in firearms. The

${ }^{10}$ A.I., 11-2, 213 , telegram no. 192 from the Minister of Colonies to the Prime Minister, Rome, 4 October 1918; 222-4, 'Conditions of an Armistice with Turkey', annex to letter no. 3320/5 from the Foreign Minister to the Minister of Colonies (confidential), Rome, 19 October 1918; 228-31, letter no. 6891 from the Minister of Colonies to the Foreign Minister (confidential), Rome, 22. October I918.

4 A.I., 1I-2, 262-3, telegram from the Foreign Minister to the Minister of Colonies (confidential), Paris, 3 November 1918 .

12 A.I., II-2, 233-53, letter and memorandum from the Minister of Colonies to the Prime Minister (confidential), Rome, 30 October 1918. Official translation into English as read by Colonel House. 
Foreign Ministry was convinced that the action was advised by the French Legation in Addis Ababa. ${ }^{43}$ The Italian representative in Addis Ababa was genuinely convinced that the French were making a bid for the role of 'moral protector' of Ethiopia, thereby acting counter to 'English and especially Italian aspirations, which may be realized as an outcome of the war and the post-war [settlement].' ${ }^{44}$ To thwart French ambitions the Colonial Ministry prepared a plan of strategy to exclude Ethiopia from the Peace Conference. Ethiopia had not participated in the war, claimed Colosimo, and therefore had no right to take part in the Peace Conference. Moreover, 'Ethiopia is not a civilized country. Slavery is freely exercised there . . . as is eviration.' Yet Ethiopia did have interests to protect. 'Who should represent her? . . . Not her own delegates because they are not suited to the task. Not a neutral State for obvious reasons. Not France. ... Nor would Ethiopia consent to [a tripartite intervention]. ${ }^{15}$ The alternative seemed clear.

Various members of the Italian Cabinet, presided over by Colosimo in the absence of Orlando, were of the opinion that Italy could benefit from a growing divergency of interests between France and England. The War Minister, Zupelli, affirmed that 'it is to our great interest to gain the support of England and to take advantage of the differing aspirations of France and England'. ${ }^{46}$ As the Italians saw it, England intended to keep Tanganyika and South-West Africa, and would need the support of Italy and France to resist American pressures. France had ambitions, it was believed, for Gambia, Sierra Leone, and the Gold Coast, and intended to keep Togo. Perhaps Colosimo's I 916 analysis of the situation would be borne out by African developments, for the English government seemed resigned to the cession of Jubaland and part of the Somaliland Protectorate to Italy. But, unfortunately, the complete cession of French Somaliland was obviously out of the question; the most Italy could hope for was that the hostile French would cede just the port of Djibouti, leaving Obock to France. ${ }^{47}$ At any rate, a talk between the British representative in Ethiopia, Thesiger, and a member of the Colonial Office gave every indication that England and Italy had a common interest in Ethopia against the commerce in arms and French influence, two aspects of the same problem. ${ }^{48}$ The way seemed open

\footnotetext{
4s A.I., 11-2, 271-2, letter no. 16488 from Acting Foreign Minister Aranzoni to the Minister of Colonies, Rome, 18 November i $\$: \$$, containing text of telegram no. xor from the Minister in Addis Ababa, in November 1018.

" A.I., II-2, 273, letter no. 16486 from the Foreign Ministry to the Minister of Colonies, Rome, 18 November 1918, containing text of telegram no. 100 from the Minister in Addis Ababa, 15 November 1918.

${ }^{45}$ A.I., II-2, 278-81, memorandum on Ethiopia from the Minister of Colonies to Secretary-General De Martino of the Foreign Ministry, 22 November 1918.

${ }^{16}$ A.I., II-2, 306-7, letter no. 22473 from Minister of War Zupelli to the Colonial Minister, Rome, 30 November 1918.

"A.I., 11-2, 308-10, memorandum entitled "The French and English Colonia! Programmes, 20 November 1918', attached to letter no. 22473.

${ }^{18}$ A.I., II-2, 318-20, minutes of a colloquium between Agnesa and the British Pepresci. . tative in Ethiopia, Thesiger, Rome, 29 November 1918.
} 
for a general settlement of Italian interests in East Africa with the aid of the British.

On 3 December 1918 Sonnino personally presented Lord Balfour with a note verbale and a copy of the 30 October memorandum shown to Colonel House. ${ }^{49}$ From London, the Italian Ambassador hopefully reported that

the imminent discussion of our colonial programme at Paris may furnish a propitious occasion for a friendly examination by Italy and England of the whole Red Sea question. From a private conversation some time ago with an authoritative and competent person, I had for a moment the impression that they are contemplating here an eventual agreement on the basis of giving us a free hand in Abyssinia.... Up to now, however, I have had no official or unofficial news. ${ }^{50}$

As for Ethiopia, the Foreign Ministry time and again instructed Colli in Addis Ababa that 'according to the Italian programme the integrity and independence [of Ethiopia] must be solemnly affirmed and guaranteed by Italy. Italian demands are inspired only by the concept of uniting in one block Italian colonial possessions.' 51 The Colonial Ministry's policy of a free hand in Ethiopia and the Foreign Ministry's policy of preserving Ethiopian independence somehow were not regarded as mutually exclusive or even slightly conflicting.

Late in January I9I9 Colosimo notified the Foreign Minister that the time was right to open discussions with France and Britain about 'zones of reciprocal economic expansion' in Ethiopia. The three Powers had to present a united front to the Ethiopian government. Colosimo, however, clearly stated that he did not want Ethiopia divided into spheres of influence, economic or political. He had no other choice after 'the malevolent indiscretion' of the French, who, evidently, had notified the Ethiopian Government of the contents of the secret Italian colonial programme. ${ }^{52}$ Clearly the Ethiopian question was becoming more complicated than the Italians would have liked. Moreover, the offer of a joint Anglo-Italian policy suggested by Thesiger met with the disapproval of the Colonial Minister, who believed that such a policy would create 'a dangerous dualism contrary to any colonizing action' ${ }^{53}$ Here again is evidence that the Italian programme would not be compatible with the preservation of Ethiopian independence.

Before more could be done, Colosimo received 'discomforting news' that the French Colonial Minister, Simon, had prepared for the disposition

40 A.I., I1-2, 334, letter no. $39517 / 355$ from De Martino to the Minister of Colonies, Rome, II December I918.

so A.I., II-2, 364-5, telegram no. 1772 from the Ambassador in London, 24 December 1918.

${ }^{51}$ A.I., 11-2, $3^{89}$, telegram from the Foreign Minister to the Minister in Addis Ababa (highly confidential), 4-5 January 1919.

${ }^{52}$ A.I., II-3, 12-13, letter no. 499 from the Minister of Colonies to the Foreign Minister, Rome, 23 January 1919.

ss $A . I$., II-3, I 5-18, letter no. 553 from the Minister of Colonies to the Foreign Minister (highly confidential), Rome, 24 January 1919. 
of the German colonies 'in a way that would render vain our appeal to the Pact of London'. ${ }^{54}$ The blow fell on 28 January, when Salvaggo Raggi, the Italian Delegate in charge of colonial matters at the Peace Conference, telegraphed that Wilson's proposal of a mandate system under a League of Nations would most likely prevail: 'it seems that the only way left us is to try to obtain a mandate to administer one of the ex-German colonies '.. preferably the Cameroons'. ${ }^{55}$ Colosimo was taken by surprise by this 'unforeseen situation, ... this unjust thesis. The Wilsonian solution shakes the very foundation of Article 13 of the Treaty of London.' In such an eventuality, then Italy too had to receive a mandated territory. ${ }^{56}$ It was clear, admitted the Colonial Minister to Orlando, that

we have been taken by surprise, and that an understanding has already been reached between England and France for the assignment of the ex-German colonies. Italian public opinion on the colonial question has been dormant till now, but it begins to take interest and anxiously follows the negotiations and we must take into consideration the spirit which animates it. ${ }^{5 ?}$

By public opinion, the Colonial Minister was referring in particular to the Convegno Nazionale Coloniale per il Dopoguerra delle Colonie (National Colonial Convention for the Post-war Future of the Colonies), held in Rome from 15 to 18 January 19r9. One of the speakers, Professor Giuseppe Stefanini, who had conducted a study of the natural resources of Italy's poor Somali colony, lamented that the Government had not expended enough effort to develop the colonial economy. Stefanini envisaged a prosperous Somalia with an economy based on commerce, agriculture, and pastoralism. For commerce, he advocated the construction of a railway from the Indian Ocean inland to the allegedly rich provinces of southern Ethiopia; skins and hides and coffee could then more easily find their way to the new Italian port of Trieste. For agriculture, Stefanini evoked a picture of fertile plantations of rubber, cotton, tobacco, and sugarcane. Echoing these resplendent and largely unrealistic hopes for Italy's colonies, the Convegno passed a series of resolutions urging the Government to adopt a vigorous colonial policy. ${ }^{58}$

But at Paris, Orlando was unable to act with any degree of force. The Prime Minister reported that 'yesterday I announced our point of view as an aspiration for an application of pure justice in favour of Italy'. All, including Wilson, agreed to this proposition, but, couched in such vague

B4 A.I., II-3, 21, telegram from the Minister of Colonies to Marchese Salvaggo Raggi, Italian Delegate to the Peace Conference, Rome, 28 January 1919.

s6 A.I., II-3, 25-6, telegram no. 261 from Salvaggo Raggi to the Minister of Colonies, Paris, 28 January I 9 I 9.

Be A.I., 11-3, 27-9, telegram no. 365 from the Minister of Colonies to the Foreign Minister (personal), Rome, 29 January 1919.

${ }^{57} A . I$, II-3, 3I, letter no. 1013 from the Minister of Colonies to the Prime Minister, Rome, 29 January 1919.

${ }^{88} \mathrm{G}$. Stefanini, Le Risorse idriche della Somalia italiana e l'Avvenire della Colonia (Rome, 1919). 
terms, the Italian demands were far from effective. Orlando, however, was a realist; to state Italy's case in a stronger fashion would have accomplished nothing. 'For our part,' wrote Orlando, 'we realize that we have neither the force nor the opportunity to sustain a struggle against Wilson and instead we will have to await the outcome [of the Conference] to see what can be done for our interests.' ${ }^{59}$ Under the circumstances, the best Orlando could hope for was 'a delay [which] would leave our colonial question up in the air'. ${ }^{60}$ Wilson favoured mandates, and the League was to select the mandatory Powers. 'In such conditions it is rather difficult to avoid misfortune for Italy short of placing ourselves clearly against President Wilson.' 61

Colosimo was shattered. A postponement of the issue meant, of course, that British and French troops remained in occupation of the German colonies. With a temporary occupation, Article I 3 could not be invoked; with the establishment of a mandates system, the maximum-minimum programme crumbled. Embittered, Colosimo wrote, 'It is evident that the French and English opposition to the Wilsonian theory was a pretence and so they easily ended up accepting it, burdening themselves with it in an attempt to evade the obligations which they have toward Italy.' Now Colosimo felt that Italy had to 'face up to our two allies' and win Wilson's support of a just settlement of Italian claims derived from the London Pact. 'Our vitally important colonial question must be resolved now or it will never be resolved.' 62

Although Colosimo's position in Rome was a strong one-he presided over the Cabinet in the absence of the Prime Minister-their close friendship did not greatly affect Orlando's point of view on the colonial question. Colosimo felt that the distribution of mandates was cause enough for the application of Article 13. Orlando, who believed that there was a possibility of Italy's receiving a mandate, reprimanded his friend for 'exaggerated words'; at the same time he admitted that there were serious obstacles in the way. Seeking the middle way, Orlando wrote, 'We will not abandon our case and we are disposed to defend it even to the extreme. But I cannot hide from you the fact that the situation is extremely grave and almost desperate, while the difficulties surrounding our general claims also increasingly impede any action by us. ${ }^{183}$ Colosimo's grandiose hopes were finally dashed on 2 February 1919, when the Prime Minister wrote, 'However great an idea we may have of Italy's rights in colonial matters,

${ }^{30}$ A.I., 11-3, 33-4, telegram no. 1013 from the Prime Minister to the Minister of Colonies, Paris, 29 January 1919.

${ }^{\circ 0}$ A.I., II-3, 35, telegram no. 1032 from the Prime Minister to the Minister of Colonies (confidential), Paris, 29 January 1919.

ol A.I., II-3, 38, telegram from the Prime Minister to the Minister of Colonies (personal), Paris, 30 January 1919.

02 A.I., II-3, 43-5, telegram no. I099 from the Minister of Colonies to the Prime Minister, Rome, 31 January igrg.

${ }^{33}$ A.I., 1I-3, 56-7, telegram no. 490 from the Prime Minister to the Minister of Colonies (highly confidential), Paris, 2 February 1919. 
the truth of the matter is that they form a relatively small part of a larger whole. ${ }^{64}$ Briefly the Colonial Minister considered the possibility of going to Paris to present Italy's case himself. He soon came to the conclusion that such an act would 'certainly be useless and perhaps harmful' and 'would increase the preoccupation of him who has so many responsibilities of a general order'. ${ }^{65}$ In principle, then, Colosimo yielded to Orlando, although he continued to believe that Article I 3 would be applied, whether or not mandates were to be distributed.

Throughout February 1919 the Allied representatives in Paris were preoccupied with the task of drafting a constitution for the League of Nations. Against this background Colosimo continued to make plans for the future. Italian demands for Jubaland were expanded. Thesiger's suggestion for an Anglo-Italian division of Ethiopia into spheres of influence was definitively rejected. Colosimo dreamed of an extension of Italian influence from Eritrea across the Red Sea to Yemen, where 'given a choice between the two Powers, for a form of protection or of assistance, there is no doubt that preference would be given Italy'. ${ }^{66}$ In March, Catastini, a member of the Italian delegation in Paris, wrote to the Minister of Colonies that the Italian delegation had drawn up a new memorandum on Italy's colonial aspirations. Colosimo, however, strongly criticized the Committee for failing to mention a return to the Protocols of $189 \mathrm{I}$ and 1894 , by which Ethiopia fell into an Italian sphere of influence. ${ }^{67}$

The trend of events in Ethiopia was particularly disturbing to Rome. Colosimo forcefully condemned two of Italy's allies for the action of their agents in East Africa:

What is taking place in Ethiopia is unique. A representative of an associated Power and a representative of an allied Power which signed a special accord for Ethiopia with us are inciting Ethiopian public opinion against Italy, making impossible peaceful discussion of the Italian programme at the Peace Conference. ... What idea can the Ethiopian Government have of the solidarity of the Allied and Associated Powers when they see France and America behaving in Ethiopia as enemies of Italy. ... .

I believe it necessary to send a protest to Wilson to give the American Consul in Aden categorical instructions to desist from his rash behaviour, [and a copy of that protest] to Lloyd George to demonstrate that what is taking place now in Addis Ababa is the most telling proof of the need to eliminate French influence from Ethiopia if Italy is to have peace in her colonies. ${ }^{68}$

${ }^{61}$ A.I., 11-3, 59-60, personal letter from Orlando to Colosimo, Paris, 2 February i 919.

Bs A.I., II-3, 77-9, letter no. 1270 from the Minister of Colonies to Salvaggo Raggi, Rome, 5 February igig.

80 A.I., II-3, 81, letter no. 1274 from the Minister of Colonies to Salvaggo Raggi, Rome, 5 February I919; 143-7, letter no. 4011 from the Foreign Minister to the Minister of Colonies, Rome, 22 February 1919; 135-6, letter no. 1318 from the Colonial Minister to the Foreign Minister (confidential), Rome, 2 I February igrg.

${ }^{\circ}$ A.I., II-3, 247-5I, letter no. 1890 from the Minister of Colonies to the Italian Delegation at Paris (confidential), Rome, 16 March igra.

${ }^{B 8}$ A.I., II-3, 299-300, letter no. 2585 from the Minister of Colonies to the Foreign Minister, Rome, II April I919. 
To add to Colosimo's woes, in mid-May there came rumours that France was about to extend a protectorate over Ethiopia. ${ }^{69}$ Interestingly enough, the Italian Ambassador in Paris doubted the claims of French intrigues in Ethiopia made by Colli in Addis Ababa. Ambassador Bonin was of the opinion that 'scarce cordiality exists between the two legations in Addis Ababa' and obviously the French Minister there would do all in his power to undermine Italy's influence. But to call this intrigue would be to go too far. Moreover, in Paris it was equally obvious that 'we should not delude ourselves by believing that the French government could be easily induced to make concessions [to Italy]'.$^{70}$

On 15 May 1919 Orlando met with Lord Milner for a preliminary conversation on colonial matters. Lord Milner raised no serious objection to a rectification of the border between Libya and Egypt and yielded completely to the Italians on the cession of Kismayu and Jubaland. As for British Somaliland, only small partial concessions could be made to the Italians because of its strategic value for the protection of Aden. Lord Milner seemed to be interested in the Italian proposal regarding Djibouti, but he entertained grave doubts that France would ever part with that colony. In accepting the principle that Italy had the right to participate in the new mandates system, the British carefully avoided any commitment to support Italian claims to any particular territory. ${ }^{71}$ Heartened by these early talks, Colosimo noted with satisfaction the British stand on the Libyan border, Kismayu, and Jubaland. In reference to acquisition of parts of the British Protectorate, he wrote, 'If Italy does not have Djibouti, the awarding to us of British Somaliland would be a lead weight tied to our feet.' Shrewdly Colosimo proposed that consideration be given to assigning Angola to Italy as a mandated territory $!^{72}$

The following day the Committee for the Application of Article i3 met for the first time. The British were represented by Lord Milner, who was elected chairman of the group. The French had as their delegate Colonial Minister Simon, while the Italians were represented by three men, an indication of weakness rather than of strength. Sonnino felt that his participation in the Committee's work would be inopportune, and therefore the Italian delegation consisted of Giacomo De Martino, Silvio Crespi, and Renato Piacentini. ${ }^{73}$ In committee the Italians presented most of the

${ }^{89}$ A.I., II-3, 332-4, letter no. 5306 from the Minister of Colonies to the Foreign Minister, Rome, I 1 May rgrg.

${ }^{70}$ A.I., 11-3, 346-9, letter no. 8885 from the Foreign Minister to the Minister of Colonies, Rome, 13 May 1919. Contains the 18 April Report of the Italian Ambassador in Paris.

${ }^{71}$ A.I., II-3, 355-7, letter from the Prime Minister to the Minister of Colonies, Paris, 15 May 1919.

${ }^{72}$ A.I., II-3, 358-6r, letter no. 549 I from the Minister of Colonies to the Prime Minister, Rome, is May igig.

${ }^{73}$ De Martino had served as Italian Governor of Somalia from rgro to 19r6; in I919 he was the Secretary-General of the Ministry of Foreign Affairs. Crespi served in Orlando's Cabinet as head of the war-time Ministry of Supplies. Piacentini was a career officer in the Colonial Ministry. 
maximum programme, which went far beyond the contents of Article I 3 . Lord Milner was reluctant even to discuss the Italian claims, while Simon declared Italy's claims exaggerated. The French Minister warned that if Italy was aiming to obtain de facto control of Ethiopia, then the question would become 'très grave'. The French thus made clear that they would not yield to Italy. De Martino quickly became aware of their attitude: 'As for Djibouti, the battle certainly will be even sharper and more difficult. ${ }^{27}$

Since Italy was outnumbered in committee, De Martino and Crespi resorted to a private lunch with Milner, who had already agreed in principle to make some concessions. Milner told the Italians that they would have an easier time obtaining Jubaland than either Djibouti or Somaliland, for the French policy in Ethiopia had been a very successful one. When Lord Milner asked what, frankly, were Italy's real intentions in Ethiopia, Crespi and De Martino assured him that Ethiopia's independence would be maintained. All Italy wanted was commercial and industrial exploitation of that land; economic colonialism was not thought of as a subtle limitation on political independence. When the Italians brought up the question of Yemen, they found that British policy was to maintain an independent Arabian peninsula outside the arena of international diplomacy. Lastly, Milner's only objection to Italian ambitions in Angola was that Portugal would demand recompense; the English representative failed to see what compensations Italy could give Portugal for her ancient colony. ${ }^{75}$

At the second meeting of the Committee for the Application of Article 13 on 19 May Simon made a concession on an insignificant point. France accepted the Italian demand for the cession of territories between Ghadames, Ghat, and Tummo, but rejected all other claims. Not unexpectedly, Simon outrightedly refused to cede Djibouti or any part of the French Somali coast. Milner, in sharp contrast to the adamant Frenchman, accepted the Italian demand for Jarabub and the new Libya-Egypt frontier; he also approved the cession of Kismayu and 83,000 square kilometres of Jubaland. England, he said, was disposed to cede Somaliland, except for the coastal area between Zeila and Berbera. Tantalizingly, Milner proposed that if France gave up Djibouti, England would concede even more to Italy. Repeating the words of the Colonial Minister, Crespi complained, 'Djibouti is the key to Italian colonial policy.' The concession in the Libyan hinterland, he said, was no equitable compensation from France. Whereupon Simon repeated bitterly that 'the true purpose of the Italian programme is to push [pousser] France out of Ethiopia'. ${ }^{76}$ The negotiations had now reached a deadlock.

\footnotetext{
74 A.I., II-3, 363-4, letter no. 2201 from De Martino to the Minister of Colonies, Paris, 16 May 1919.

is A.I., II-3, 366-7, letter no. 536 from the Foreign Minister to the Minister of Colonies, Paris, 16 May 1919.

76 A.I., II-3, 382-5, letter no. 552 from the Foreign Minister to the Minister of Colonies, Paris, 20 May 1919.
} 
Meanwhile De Martino met with an agent of Alfonso Costa, former President of Portugal and now head of the Portuguese delegation to the Peace Conference, in order to investigate the possibility of an ItaloPortuguese accord on Angola. The Portuguese, it was discovered, 'would cede the rights of complete exploitation of Angola to an Italian company under the control of the Italian government; a special accord would be concluded with France and England to exclude them from any activity in Angola'. Apparently the project also met with the approval of Augusto Soares, ex-Foreign Minister of Portugal, who was in Paris as a member of the Portuguese delegation. ${ }^{77}$ Talks with the Portuguese continued from 26 to 28 May, but hopes of Italian entry into Angola proved to be in vain.

On 29 May the Committee on Article 13 held its third meeting. Simon repeated his offer of limited concessions in Tripolitania, but otherwise there was an impasse. Colosimo, dejected by the obvious failure of Italy to secure his programme, telegraphed Orlando:

It appears that there is nothing more to hope for, except the rectification of the borders in North Africa; the cession of a part of British Somaliland, which it would be a great mistake to accept, for without Djibouti it would bring us burdens and not benefits; and the definition of Kismayu. No mandates were assigned to us. In sum, the colonial question, of the highest importance to Italy, is about to resolve itself in betrayal. The last hope is action by you in the next discussion of the Big Four. ${ }^{78}$

Colosimo, in fact, was concerned not only that Italy would not get Djibouti, but that in the process of negotiations, 'the greatest injury to our situation in Ethiopia is presenting itself-the menace of our being excluded '. ${ }^{79}$

The fourth meeting of the Committee on Article I $_{3}$ took place on 30 May. There the deadlock between France and Italy continued. Accepting the British offers of Jarabub and the Libyan border and of Jubaland, Crespi demanded an Italian mandate over Togo as compensation for not receiving Djibouti. But there the Italians were called to a halt by Lord Milner, who declared that an Italian mandate claim was not consonant with the contents of Article 13. Under the circumstances nothing else could be done. The Committee ended its work in failure; it was agreed that the colonial question should be placed in the hands of the Committee of Four. ${ }^{80}$

The Italians were at a distinct disadvantage at Versailles. Finding the general situation unfavourable for Italy, Orlando could not press the French and English. Nor could Orlando count on American support for a patently anti-Wilsonian programme. He and Sonnino had already walked

${ }^{77}$ A.I., 11-3, 383-5, letter no. 552 from the Foreign Minister to the Minister of Colonies, Paris, 20 May 1919.

${ }^{78}$ A.I., $11-3,399-400$, letter no. 5959 from the Minister of Colonies to the Prime Minister, Rome, 25 May 1919.

${ }^{70}$ A.I., 11-3, 422-3, letter no. 6115 from the Minister of Colonies to the Foreign Minister, Rome, 30 May 1919.

${ }^{80}$ A.I., $11-3,424-7$, letter no. 622 from the Foreign Minister to the Minister of Colonies, Paris, 3 I May 1919. 
out of the Peace Conference once before (2I April to 5 May). The best Orlando could do was to stall for time. On 6 June 1919 the Committee for the Application of Article 13 suspended its debates, after acknowledging the divergent views of the member-States. Resignedly, Colosimo accepted the inevitable conclusion to these negotiations:

It is just as well that the Committee did not come to any conclusions. ... Faced with the persistent inflexible intransigence of the French, the likes of which I find it difficult to believe ... it is doubtless preferable to leave open the question of African colonies rather than accept ... solutions which would definitively condemn the future of Italian colonialism in Africa. ${ }^{81}$

Thus, the ambitious colonial programme framed by Italy came to naught. The Allied Powers, certainly not motivated completely by altruistic goals in their own colonial programme, did not welcome the frankly expansionist nineteenth-century policy of the Italians, who had not presented their allies with their complete programme until late in 19I8. Public opinion abroad, the Minister of Colonies had discovered, offered little encouragement for Italian aspirations. ${ }^{82}$ Keeping in mind the failure of Italy to derive any great material benefits from either her Eritrean or her Somali colony, the Colonial Minister had come to the conclusion that the future of Italian colonialism was of necessity a part of the general international problems of the war and its aftermath and 'must be considered by our allies and resolved together with us'. ${ }^{83}$ It had not been long, however, before the Italians discovered that their war-time allies would not agree to underwrite the complete Italian programme, maximum or minimum. Britain and France were no longer in the weak position they occupied when they supported Italian demands in the Balkans and Asia Minor in the Treaty of London. Now Italy was in the weak position; her failure to declare war on Germany until 28 August 1916 had done much to make her allies disgusted with her expectations. Italy failed to obtain from her French and British allies the cession of their Red Sea colonies or their agreement to the abandonment of the guaranteed independence of Ethiopia. All that Orlando and Sonnino could glean from the otherwise rich colonial harvest was an English agreement in principle to the cession of Kismayu and Jubaland. Dissatisfied Italians had shared Colosimo's hope that Italy would finally attain undisputed Great Power status through creation of an African empire, but a peace settlement embodying much of the Colonial Minister's ambitious programme proved to be out of the question. He and his countrymen were forced to be content with a few crumbs from the private banquet table of their allies.

${ }^{81}$ A.I., 11-3, 547-8, letter no. 2144 from the Minister of Colonies to the Foreign Minister, Rome, I6 June 1919.

${ }^{82}$ A.M.A.I., pos. $16 \mathrm{I} / \mathrm{I}$, f. 5, letter from the Minister of Colonies to the Foreign Minister (confidential, personal), Rome, 3 June 1918.

ss A.M.A.I., pos. $161 / 1$, f. 5, personal letter from Colosimo to Orlando, Rome, 7 June 1918. 